\title{
PENGARUH FASILITAS KERJA, KEDISIPLINAN DAN PENGAWASAN TERHADAP KINERJA PEGAWAI DINAS PERIKANAN KOTA TANJUNGBALAI
}

\author{
${ }^{1}$ Elfina Manurung, ${ }^{2}$ Eko Topan Prihatin Nura, ${ }^{3}$ Nurdin,,${ }^{4}$ Tengku Anggi Metia, ${ }^{5}$ Isminingsih \\ $1,2,3,4,5$ Universitas Islam Sumatera Utara \\ I'elfina.manurung@gmail.com, ${ }^{2}$ eko.topan@gmail.com, ${ }_{5}^{3}$ nurdin.mm@gmail.com, 4 tengku.metia@gmail.com, \\ 5isminingsih.mm@gmail.com
}

\begin{abstract}
The formulation of the problem in this research is: How do work facilities, discipline and supervision influence the employees performance at Dinas Perikanan Kota Tanjungbalai. This study aims to determine the effect of work facilities, discipline and supervision on employee performance. With total sampling technique, the sample in this study was 41 people. The results showed; Work facilities partially have a positive effect on employee performance; Discipline partially has a positive effect on employee performance; Partial supervision has a positive effect on employee performance; Work facilities, discipline and supervision have a positive and significant effect on employee performance.
\end{abstract}

Keywords : Work Facilities, Discipline; Supervision; Employee Performance

ABSTRAK : Rumusan masalah dalam penelitian ini adalah : Bagaimana pengaruh fasilitas kerja, kedisiplinan dan pengawasan terhadap kinerja pegawai di Dinas Perikanan Kota Tanjungbalai. Penelitian ini bertujuan untuk mengetahui pengaruh fasilitas kerja, kedisiplinan dan pengawasan terhadap kinerja pegawai. Dengan teknik penarikan sampel secara Total Sampling maka sampel dalam penelitian ini sebanyak 41 orang. Hasil penelitian menunjukkan; Fasilitas kerja secara parsial berpengaruh positif terhadap kinerja pegawai; Kedisiplinan secara parsial berpengaruh positif terhadap kinerja pegawai; Pengawasan secara parsial berpengaruh positif terhadap kinerja pegawai; Fasilitas kerja, kedisiplinan dan pengawasan berpengaruh positif dan signifikan terhadap kinerja pegawai.

Kata Kunci : Fasilitas Kerja, Kedisiplinan; Pengawasan; Kinerja Pegawai

\section{Pendahuluan}

Kinerja (performance) merupakan kombinasi dari efektivitas dengan efisiensi pada saat melakukan tugas pokok pekerjaan (Robbins, 2016:396)". Kinerja yang baik adalah kinerja yang optimal, yaitu kinerja yang sesuai standar organisasi dan mendukung tercapainya tujuan organisasi. Sebuah organisasi harus berusaha meningkatkan kemampuan sumber daya manusianya, karena hal tersebut merupakan faktor kunci untuk meningkatkan kinerja pegawai. Peningkatan kinerja pegawai akan membawa kemajuan bagi instansi untuk dapat bertahan dalam suatu persaingan lingkungan kerja yang tidak stabil. Oleh karena itu upaya-upaya untuk meningkatkan kinerja pegawai merupakan tantangan manajemen yang paling serius karena keberhasilan untuk mencapai tujuan dan kelangsungan hidup instansi tergantung pada kualitas kinerja sumber daya manusia yang ada didalamnya.

Faktor - faktor kinerja pegawai sangat dipengaruhi oleh fasilitas kerja, kedisiplinan dan pengawasan. Fasilitas dapat diartikan sebagai segala sesuatu yang dapat memudahkan dan memperlancar pelaksanaan segala sesuatu pekerjaan. Adapun yang dapat memudahkan dan melancarkan pekerjaan ini dapat berupa bendabenda maupun uang, jadi dalam hal ini fasilitas dapat disamakan dengan sarana yang ada di kantor. Fasilitas kerja adalah sarana pendukung dalam aktivitas instansi berbentuk fisik, dan digunakan dalam kegiatan normal instansi, memiliki jangka waktu kegunaan yang relatif permanen dan memberikan manfaat untuk masa yang akan datang. Fasilitas 
kerja sangatlah penting bagi instansi, karena dapat menunjang kinerja pegawai, seperti dalam penyelesaian pekerjaan.

Selain itu, "Fasilitas kerja itu sendiri adalah segala sesuatu yang digunakan, dipakai, ditempati dan dinikmati oleh pegawai baik dalam hubungan langsung dengan pekerjaan maupun untuk kelancaran pekerjaan (Moenir,2013:197)". Dalam setiap segi proses pekerjaan yang produktif, maka instansi harus berusaha menyediakan fasilitas kerja yang lengkap dan memadai guna menunjang proses jalannya pekerjaan. Apabila fasilitas kerja sudah lengkap dan baik maka diharapkan dapat mempengaruhi kinerja para pegawai. Seperti yang diungkapkan oleh Sunyoto (2013:45) bahwa "Segenap yang diperlukan dalam mengerjakan atau menyelesaikan pekerjaan merupakan suatu hal yang harus dipenuhi oleh organisasi, tentunya dengan harapan semakin lengkap fasilitas yang dimiliki akan semakin baik dan produktivitasnya mengalami peningkatan yang berarti”.

Selain fasilitas kerja, kinerja juga dapat dicapai oleh seseorang atau sekelompok orang dalam suatu organisasi dengan kedisiplina yang sesuai dengan wewenang dan tanggung jawab masing-masing, agar disiplin kerja dapat tumbuh pada setiap diri pegawai. Kinerja dapat diukur dari sikap disiplin yang dimiliki masingmasing pegawai, disiplin kerja yang tinggi secara otomatis akan menghasilkan kinerja yang baik pula. Disiplin merupakan kegiatan manajemen untuk menjalankan standar-standar operasional, setiap pegawai harus mempunyai kesadaran secara internal akan kedisiplinan terhadap pekerjaannya sebab rata-rata individu lebih memahami apa yang diharapkan dalam pekerjaannya. Pendisiplinan pegawai adalah suatu bentuk pelatihan yang berusaha memperbaiki dan membentuk pengetahuan, sikap dan perilaku pegawai sehingga para pegawai secara sukarela berusaha bekerja secara kooperatif dengan pegawai yang lain serta meningkatkan kinerjanya ( Handoko, $2011: 204$ ).

Penerapan disiplin merupakan hal yang harus diperhatikan dalam pelaksanaan pekerjaan, dengan kata lain disiplin itu bukan sekedar kepatuhan terhadap perintah akan tetapi sebagai suatu sikap serta perbuatan yang timbul dari dalam diri pegawai untuk bertanggung jawab serta mengikuti kewajiban dan peraturanperaturan yang dibentuk sehingga tanggung jawab melekat pada disiplin tersebut maupun mempengaruhi tugas-tugas yang dilaksanakan.

Dalam meningkatkan kinerja pegawai, instansi juga perlu memperhatikan pengawasan dari atasan kepada pegawai. Pengawasan merupakan tindakan atau kegiatan yang dilakukan oleh pimpinan untuk mengetahui apakah jalannya pekerjaan dan hasilnya sesuai dengan rencana. Kinerja juga sangat dipengaruhi oleh tingkat pengawasan pada saat jam kerja sedang berlangsung. Pengawasan yang tidak optimal dapat memungkinkan pegawai untuk bertindak semaunya sendiri bahkan bisa melakukan pelanggaran yang bertentangan dengan aturan yang berlaku di instansi ( Hasibuan : 2010 : 242 ). Pengawasan yang dilakukan dengan baik, maka pekerjaan akan berjalan dengan lancar dan dapat menghasilkan hasil kerja yang baik pula. Selain itu, melalui pengawasan dapat dipantau berbagai hal yang dapat merugikan organisasi antara lain kesalahan dalam pekerjaannya, kekurangan dalam pelaksanaan pekerjaan, kelemahan pelaksanaan dan cara kerjanya. Akan tetapi pengawasan yang dilaksanakan pimpinan bukanlah untuk mencari-cari kesalahan, melainkan ditujukan agar dapat dilaksanakan dengan sebaik-baiknya. Selain itu dibutuhkan juga pengawasan yang berkelanjutan agar dapat menghasilkan dampak positif untuk perkembangan dan perubahan yang lebih baik. Salah satu upaya dalam memaksimalkan potensi sumber daya manusia (SDM) adalah melalui penegakan disiplin pegawai.

Pengawasan yang baik akan memberikan efek yang baik pula karena pegawai akan menyelesaikan pekerjaan tepat waktu sesuai dengan target waktu pekerjaan yang ditetapkan. Menurut peneliti pengawasan penting di Dinas Perikanan Kota Tanjungbalai karena masih ada pegawai yang melakukan kesalahan dan pelanggaran sehingga visi dan misi dari kantor tidak akan tercapai.

Hasil kerja merupakan tolak ukur penilaian pimpinan terhadap pegawai, sehingga pengawasan sangat perlu dilakukan setiap hari yang bertujuan untuk mengevaluasi hasil kerja pegawai. Pengawasan yang tinggi akan menciptakan pengaruh yang positif terhadap pegawai, dimana mereka mempunyai keinginan dan kesadaran yang besar untuk menyelesaikan pekerjaan sesuai dengan target yang ditetapkan. 
Berdasarkan pengamatan awal yang dilakukan peneliti yang sesuai dengan variabel penelitian ini pada Dinas Perikanan Kota Tanjungbalai terlihat bahwa :

a. Fasilitas kerja yang tersedia belum cukup memadai seperti kurangnya alat- alat elektronik yang mampu menunjang proses kerja pegawai sehingga berpengaruh pada kinerja pegawai dalam menyelesaikan pekerjaannya

b. Disiplin kerja pegawai Dinas Perikanan Kota Tanjungbalai kurang baik terbukti dengan sebanyak $40 \%$ pegawai sering datang terlambat masuk kerja, 20\% pegawai yang tidak masuk kerja dengan alasan diluar urusan pekerjaan kantor, $45 \%$ pegawai yang tidak tepat waktu dalam melaksanakan pekerjaannya.

c. Pengawasan yang dilakukan atasan terhadap pegawai masih kurang efektif, tidak menetapkan standar waktu untuk mengukur kinerja pegawai, atasan kurang tegas dalam memberikan peringatan dan sanksi apabila ada pegawai yang melakukan kesalahan atau penyimpangan, dan pengawasan yang dilakukan atasan tidak setiap hari sehingga masih ada pegawai yang melakukan kesalahan.

\subsection{Rumusan Masalah}

Berdasarkan latar belakang masalah tersebut diatas, maka yang menjadi rumusan masalah dalam penelitian ini adalah :

a. Bagaimana pengaruh fasilitas kerja terhadap kinerja pegawai di Dinas Perikanan Kota Tanjungbalai ?

b. Bagaimana pengaruh kedisiplinan terhadap kinerja pegawai di Dinas Perikanan Kota Tanjungbalai ?

c. Bagaimana pengaruh pengawasan terhadap kinerja pegawai di Dinas Perikanan Kota Tanjungbalai ?

d. Bagaimana pengaruh fasilitas kerja, kedisiplinan dan pengawasan secara bersama-sama terhadap kinerja pegawai di Dinas Perikanan Kota Tanjungbalai ?

\subsection{Batasan Masalah}

Dalam penelitian ini hanya meneliti tentang pengaruh fasilitas kerja, kedisiplinan dan pengawasan terhadap kinerja pegawai di Dinas Perikanan Kota Tanjungbalai.

\subsection{Hioptesis}

Hipotesis adalah jawaban sementara yang kebenaranya masih harus diuji,atau rangkuman kesimpulan teoritis yang diperoleh dari tinjauan pustaka. Dengan demikian hipotesis dalam penelitian ini adalah

1. Secara parsial ada pengaruh fasilitas kerja terhadap kinerja pegawai Dinas Perikanan Kota Tanjungbalai

2. Secara parsial ada pengaruh kedisiplinan terhadap kinerja pegawai Dinas Perikanan Kota Tanjungbalai

3. Secara parsial ada pengaruh pengawasan terhadap kinerja pegawai Dinas Perikanan Kota Tanjungbalai

4. Secara simultan ada pengaruh fasilitas kerja, kedisiplinan dan pengawasan terhadap kinerja pegawai Dinas Perikanan Kota Tanjungbalai

\subsection{Tujuan Penelitian}

Tujuan yang hendak dicapai dalam penelitian ini yaitu:

a. Untuk mengetahui pengaruh fasilitas kerja terhadap kinerja pegawai di Dinas Perikanan Kota Tanjungbalai.

b. Untuk mengetahui pengaruh kedisiplinan terhadap kinerja pegawai di Dinas Perikanan Kota Tanjungbalai

c. Untuk mengetahui pengaruh pengawasan terhadap kinerja pegawai di Dinas Perikanan Kota Tanjungbalai

d. Untuk mengetahui pengaruh fasilitas kerja, kedisiplinan dan pengawasan terhadap kinerja pegawai di Dinas Perikanan Kota Tanjungbalai

\section{Metode Penelitian \\ 2.1. Populasi}

Populasi adalah wilayah generalisasi yang terdiri atas subjek atau objek yang mempunyai kualitas dan karakteristik tertentu yang ditetapkan oleh peneliti untuk dipelajari dan kemudian ditarik kesimpulannya, Sugiono (2013 :80). Dalam penelitian ini yang menjadi populasi penelitian adalah seluruh pegawai Dinas Perikanan Kota Tanjungbalai yang berjumlah 43 orang dan dapat dijelaskan dengan kerangka populasi sebagai berikut : 
Tabel 1. Kerangka Populasi Berdasarkan Jabatan Thn. 2020

\begin{tabular}{|r|l|c|}
\hline No & \multicolumn{1}{|c|}{ Jabatan } & Jlh Populasi \\
\hline 1 & Kepala Dinas & 1 \\
\hline 2 & Sekretaris & 1 \\
\hline 3 & Kepala Bidang & 1 \\
\hline 4 & Bendahara & 2 \\
\hline 5 & Ka.Seksi & 2 \\
\hline 6 & Bagian Pengadministrasi & 7 \\
\hline 7 & Bagian Pengelola & 3 \\
\hline 8 & Analis dan Peramu Benih & 2 \\
\hline 9 & Pelaksana Jabatan & 14 \\
\hline 10 & Honorer $\quad$ Jumlah & $\mathbf{4 3}$ \\
\hline \multicolumn{2}{|c|}{} \\
\hline
\end{tabular}

Sumber: Dinas Perikanan Kota Tanjungbalai - 2020

\subsection{Sampel}

Sampling Sampel adalah bagian dari populasi yang sengaja dipilih oleh peneliti untuk diamati, sehingga sampel ukurannya lebih kecil dibandingkan populasi dan berfungsi sebagai wakil dari populasi ( Nurhayati, 2012 : 36 ). Teknik pengambilan sampel dalam penelitian ini adalah total sampling. Total sampling adalah teknik pengambilan sampel dimana jumlah sampel sama dengan populasi, Sugiyono (2010; 130). Alasan mengambil total sampling karena menurut Sugiyono jumlah populasi yang kurang dari 100 seluruh populasi dijadikan sampel penelitian semuanya

Dengan teknik penarikan sampel secara Total Sampling maka sampel dalam penelitian ini adalah seluruh populasi yaitu Dinas Perikanan Kota Tanjungbalai sebanyak 41 orang. Karena Kepala Dinas dan Peniliti Sebagai Kasi Kemitraan Usaha, Informasi Dan Teknologi Perikanan tidak ikut di teliti dalam penelitian ini.

Tabel 2. Kerangka Sampel Berdasarkan Jabatan Thn. 2020

\begin{tabular}{|r|l|r|r|c|}
\hline No & Jabatan & Jlh Populasi & Jlh. Sampel & Keterangan \\
\hline 1 & Kepala Dinas & 1 & - & Tidak \\
\hline 2 & Sekretaris & 1 & 1 & Di teliti \\
\hline 3 & Kepala Bidang & 1 & 1 & Di teliti \\
\hline 4 & Bendahara & 2 & 2 & Di teliti \\
\hline 5 & Ka.Seksi & 2 & 1 & 1 Peneliti \\
\hline 6 & Bagian Pengadministrasi & 7 & 7 & Di teliti \\
\hline 7 & Bagian Pengelola & 2 & 3 & Di teliti \\
\hline 8 & Analis dan Peramu Benih & 14 & 2 & Di teliti \\
\hline 9 & Pelaksana Jabatan & 10 & 14 & Di teliti \\
\hline 10 & Honorer & $\mathbf{4 3}$ & $\mathbf{4 1}$ & Di teliti \\
\hline & Jumlah & & &
\end{tabular}

Sumber: Dinas Perikanan Kota Tanjungbalai-2020

\subsection{Uji Normalitas}

Pengujian normalitas data bertujuan untuk melihat normal tidaknya sebaran data yang akan dianalisis. Model regresi yang baik adalah distribusi normal atau mendekati normal. Untuk melihat normalitas data ini digunakan pendekatan grafik yaitu Normality Probability Plot.
Deteksi normalitas dengan melihat penyebaran data (titik) pada sumbu diagonal dari grafik. Menurut Santoso (2014:214), dasar pengambilan keputusan adalah:

a. Jika data menyebar disekitar garis diagonal dan mengikuti arah garis diagonal, maka model regresi memenuhi asumsi normalitas. 
b. Jika data menyebar jauh dari garis diagonal dan atau tidak mengikuti arah garis diagonal, maka model regresi tidak memenuhi asumsi normalitas. Pada output SPSS versi 24.00 bagian normal $P$-P Plot of Regresion Standardized Residual, dapat dijelaskan bahwa data-data (titiktitik) cenderung lurus mengikuti garis diagonal sehingga data dalam penelitian ini cenderung berdistribusi normal, seperti terlihat pada gambar dibawah ini.

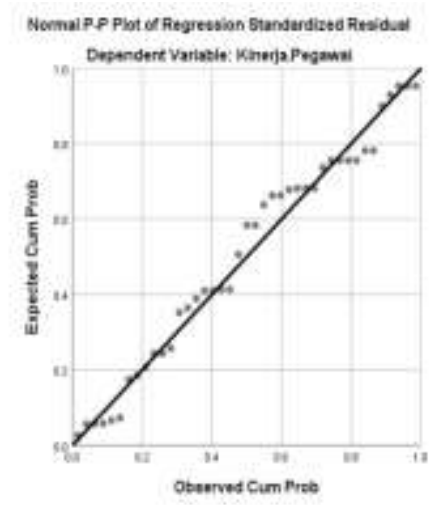

Gambar 1. Normalitas Data

\subsection{Uji Multikolinearitas}

Pengujian multikolinearitas dilakukan untuk melihat apakah pada model regresi ditemukan adanya korelasi antara variabel bebas. Jika terjadi korelasi, maka dinamakan terdapat problem multikolinearitas. Cara mendeteksinya adalah dengan melihat nilai Variance Inflation Factor (VIF). Menurut Santoso (2014:203), pada umumnya jika VIF lebih besar dari 5, maka variabel bebas tersebut mempunyai persoalan multikolinearitas dengan variabel bebas lainnya.

Pada ouput SPSS bagian Coefficient, semua angka VIF berada dibawah 5, hal ini menunjukan tidak terjadi multikolinearitas, seperti dapat dilihat pada tabel dibawah ini.

Tabel 3. Uji Multikolinearitas

\begin{tabular}{|l|l|l|l|}
\hline \multicolumn{3}{|c|}{ Coefficients } \\
\hline \multicolumn{2}{|l|}{ Model } & Collinearity Statistics \\
\cline { 3 - 4 } \multicolumn{2}{|c|}{1} & Tolerance & VIF \\
\hline \multirow{3}{*}{1} & (Constant) & & \\
\cline { 2 - 4 } & & & \\
\cline { 2 - 4 } & Fasilitas.Kerja & .724 & 1.380 \\
\cline { 2 - 4 } & Kedisiplinan & .770 & 1.299 \\
\cline { 2 - 4 } & Pengawasan & .637 & 1.571 \\
\hline
\end{tabular}

a. Dependent Variable: kinerja.pegawai

\subsection{Uji Heteroskedastisitas}

Pengujian heteroskedastisitas bertujuan untuk melihat apakah dalam sebuah model regresi terjadi ketidaksamaan varians dari residual yang merupakan suatu pengamatan ke pengamatan yang lainnya. Jika varians dari residual yang merupakan suatu pengamatan ke pengamatan yang lain bernilai tetap, maka hasil data disebut homoskedastisitas dan jika varians berbeda atau bernilai tidak tetap maka disebut heteroskedastisitas. Model regresi yang baik adalah model yang bernilai tetap atau homoskedastisitas atau tidak terjadi heteroskedastisitas.

Deteksi heteroskedastisitas dilakukan dengan cara melihat ada tidaknya pola tertentu pada data yang diolah. Menurut Santoso (2014:208), dasar pengambilan keputusannya adalah:

a. Jika pola tertentu seperti titik-titik yang ada membentuk suatu pola tertentu yang teratur, maka terdapat situasi heteroskedastisitas.

b. Jika tidak ada pola yang jelas, serta titiktitik menyebar diatas dan dibawah angka nol pada sumbu Y, maka tidak terjadi heteroskedastisitas.

Pada output SPSS dibagian Scatrerplot, terlihat titk-titik menyebar secara acak, tidak membentuk sebuah pola tertentu yang jelas, serta tersebar baik diatas maupun dibawah angka nol pada sumbu Y. Hal ini berarti tidak terjadi heterskedastisitas pada model regresi, sehingga model regresi layak dipakai. Pola Scatterplot dapat dilihat pada gambar dibawah ini.

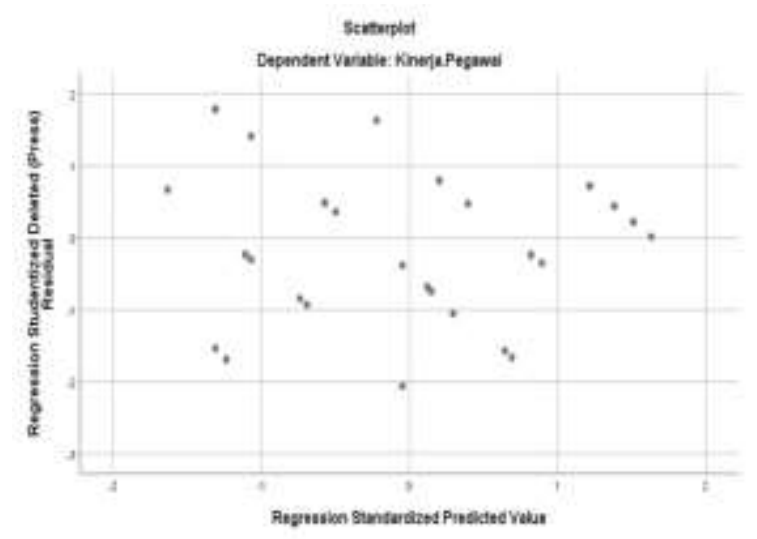

Gambar 2. Uji Heteroskedastitas

\section{Evaluasi Data (Analisa Regresi Linier}

\section{Berganda )}

\subsection{Pengujian Hipotesis}

Dalam evaluasi data ini penulis akan melakukan pengujian hipotesis, baik secara partial ataupun secara simultan. Selanjutnya 
untuk mempermudah dalam evaluasi data ini, lunak komputer yaitu program SPSS maka penulis mencari niali-nilai yang V.24.00 for windows dengan hasil data dibutuhkan dengan menggunakan perangkat sebagai berikut:

Tabel 4. Hasil Uji Statistik Keofesien Regresi

\begin{tabular}{|c|c|c|c|c|c|c|}
\hline \multicolumn{7}{|c|}{ Coefficients $^{\mathbf{a}}$} \\
\hline \multicolumn{2}{|c|}{ Model } & \multicolumn{2}{|c|}{$\begin{array}{l}\text { Unstandardized } \\
\text { Coefficients }\end{array}$} & \multirow{2}{*}{$\begin{array}{c}\begin{array}{l}\text { Standardized } \\
\text { Coefficients }\end{array} \\
\text { Beta }\end{array}$} & \multirow[t]{2}{*}{$\mathrm{t}$} & \multirow[t]{2}{*}{ Sig. } \\
\hline & & B & Std. Error & & & \\
\hline \multirow{4}{*}{1} & (Constant) & 1.483 & 4.286 & & .346 & .731 \\
\hline & Fasilitas.Kerja & .407 & .096 & .406 & 4.249 & .000 \\
\hline & Kedisiplinan & .268 & .087 & .287 & 3.095 & .004 \\
\hline & Pengawasan & .351 & .090 & .397 & 3.890 & .000 \\
\hline
\end{tabular}

a. Dependent Variable: kinerja.pegawai

Berdasarkan tabel 4 diatas dapat dibuat persamaan regresi sebagai berikut:

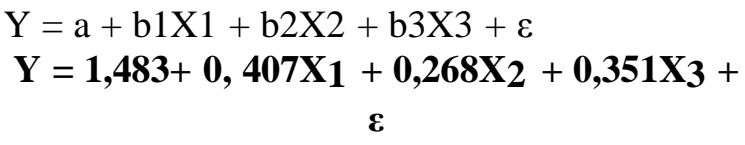

Persamaan diatas dijelaskan bahwa koefesien fasilitas kerja mempunyai nilai positif yaitu 0,407, hal ini menunujukan bahwa variabel fasilitas kerja mempunyai pengaruh positif terhadap kinerja pegawai.

Berdasarkan persamaan diatas bahwa koefesien kedisiplinan memiliki nilai positif yaitu 0,268. Hal ini menunjukan bahwa variabel kedisiplinan mempunyai pengaruh positif terhadap kinerja pegawai.

Berdasarkan persamaan diatas bahwa koefesien pengawasan juga memiliki nilai positif yaitu 0,351. Hal ini menunjukan bahwa variabel pengawasan juga mempunyai pengaruh positif terhadap kinerja pegawai.

\subsection{Pengujian Secara Simultan (Uji F)}

Untuk melihat hasil seberapa besar pengaruh yang di berikan variabel independen terhadap dependen secara simultan ( bersamasama ) pada penelitian ini maka dapat di jelaskan pada tabel di bawah ini :

Tabel 5. Hasil Uji Statistik Secara Simultan

\begin{tabular}{|c|c|c|c|c|c|c|}
\hline \multicolumn{7}{|c|}{ ANOVA $^{\mathbf{a}}$} \\
\hline \multicolumn{2}{|c|}{ Model } & Sum of & df & Mean Square & $\mathrm{F}$ & Sig. \\
\hline \multirow[t]{3}{*}{1} & Regression & 50.191 & 3 & 16.730 & 37.984 & $.000^{4}$ \\
\hline & Residual & 16.297 & 37 & .440 & & \\
\hline & Total & 66.488 & 40 & & & \\
\hline \multicolumn{7}{|c|}{ a. Dependent Variable: Kinerja.Pegawai } \\
\hline \multicolumn{7}{|c|}{ b. Predictors: (Constant), Pengawasan, Kedisiplinan, Fasilitas.Kerja } \\
\hline
\end{tabular}

Pada tabel 5. diatas terlihat bahwa nilai Fhitung adalah 37,984 dan nilai signifikansi 0,000. Diketahui nilai $F$ tabel dengan tingkat kepercayaan $95 \% \quad(\alpha: 0,05)$ adalah 2,840. Oleh karena itu nilai Fhitung $>$ Ftabel $(37,984$ $>2,840$ ) maka $\mathrm{H}_{\mathrm{O}}$ ditolak dan menerima hipotesis dalam penelitian ini yaitu bahwa fasilitas kerja, kedisiplinan dan pengawasan berpengaruh positif dan signifikan terhadap kinerja pegawai Dinas Perikanan Kota Tanjungbalai sebesar 37,984

\subsection{Pengujian Secara Parsial (Uji t)}


Tabel 6. Hasil Uji Parsial Variabel X Terhadap Y

\begin{tabular}{|c|c|c|c|c|c|c|}
\hline \multicolumn{7}{|c|}{ Coefficients $^{\mathbf{a}}$} \\
\hline \multirow{2}{*}{\multicolumn{2}{|c|}{ Model }} & \multicolumn{2}{|c|}{$\begin{array}{l}\text { Unstandardized } \\
\text { Coefficients }\end{array}$} & \multirow{2}{*}{$\begin{array}{l}\text { Standardized } \\
\text { Coefficients } \\
\text { Beta }\end{array}$} & \multirow[t]{2}{*}{$\mathrm{t}$} & \multirow[t]{2}{*}{ Sig. } \\
\hline & & B & Std. Error & & & \\
\hline \multirow{4}{*}{1} & (Constant) & 1.483 & 4.286 & & .346 & .731 \\
\hline & Fasilitas.Kerja & .407 & .096 & .406 & 4.249 & .000 \\
\hline & Kedisiplinan & .268 & .087 & .287 & 3.095 & .004 \\
\hline & Pengawasan & .351 & .090 & .397 & 3.890 & .000 \\
\hline
\end{tabular}

a. Dependent Variable: kinerja.pegawai

\subsubsection{Pengaruh Fasilitas Kerja Terhadap Kinerja Pegawai}

Untuk mengetahui secara parsial pengaruh fasilitas kerja terhadap kinerja pegawai dapat dilihat pada tebel 6 diatas. Berdasarkan tabel tersebut diperoleh nilai thitung sebesar 4,249 dan nilai signifikansi 0,000 . Sedangkan nilai tabel pada tingkat kepercayaan $95 \%(\alpha: 0,05)$ adalah 2,021. Oleh karena itu nilai thitung $>$ tabel $(4,249>2,021)$ maka $\mathrm{H}_{\mathrm{O}}$ ditolak dan menerima hipotesis dalam penelitian ini yaitu fasilitas kerja secara parsial berpengaruh positif terhadap kinerja pegawai Dinas Perikanan Kota Tanjungbalai sebesar 4,249.

\subsubsection{Pengaruh Kedisiplinan Terhadap Kinerja Pegawai}

Untuk mengetahui secara parsial pengaruh kedisiplinan terhadap kinerja pegawai, dapat dilihat pada tebel 6 diatas. Berdasarkan tabel tersebut diperoleh nilai thitung sebesar 3,095 dan nilai signifikansi 0,004 . Sedangkan nilai tabel pada tingkat kepercayaan $95 \%(\alpha: 0,05)$ adalah 2,021. Oleh karena itu nilai thitung $>$ tabel $(3,095>2,021$ ) maka $\mathrm{H}_{\mathrm{O}}$ ditolak dan menerima hipotesis dalam penelitian ini yaitu kedisiplinan secara parsial berpengaruh positif terhadap kinerja pegawai Dinas Perikanan Kota Tanjungbalai sebesar 3,095.

\subsubsection{Pengaruh Pengawasan Terhadapa Kinerja Pegawai}

Untuk mengetahui secara parsial pengaruh pengawasan terhadap kinerja pegawai, dapat dilihat pada tebel 6 diatas. Berdasarkan tabel tersebut diperoleh nilai thitung sebesar 3,890 dan nilai signifikansi 0,000 . Sedangkan nilai tabel pada tingkat kepercayaan 95\% $(\alpha: 0,05)$ adalah 2,021. Oleh karena itu nilai thitung $>$ ttabel $(3,890>2,021$ ) maka $\mathrm{H}_{\mathrm{O}}$ ditolak dan menerima hipotesis dalam penelitian ini yaitu variabel pengawasan secara parsial berpengaruh positif terhadap kinerja pegawai Dinas Perikanan Kota Tanjungbalai sebesar 3,890.

\subsection{Uji Koefisien Determinasi $\left(\mathbf{R}^{2}\right)$}

Uji determinan adalah uji yang dilakukan untuk mengetahui seberapa besar pengaruh variabel independent ( fasilitas kerja, kedisiplinan dan pengawasan ) terhadap variabel dependent ( kinerja pegawai ). Untuk melihat hasil uji determinan maka dapat diketahui nili $\mathrm{R}$ Square atau koefesien determinasi dan dapat dilihat dibawah ini.

Tabel 7. Model Summary

\begin{tabular}{|c|c|c|c|c|c|c|}
\hline \multicolumn{7}{|c|}{ Model Summary } \\
\hline \multirow[t]{2}{*}{ Model } & \multirow[t]{2}{*}{$\mathrm{R}$} & \multirow[t]{2}{*}{ R Square } & \multirow{2}{*}{$\begin{array}{l}\text { Adjusted R } \\
\text { Square }\end{array}$} & \multirow{2}{*}{$\begin{array}{l}\text { Std. Error of } \\
\text { the Estimate }\end{array}$} & \multicolumn{2}{|c|}{ Change Statistics } \\
\hline & & & & & $\begin{array}{c}\text { R Square } \\
\text { Change }\end{array}$ & F Change \\
\hline 1 & $869^{\circ}$ & .755 & .735 & .66367 & .755 & 37.984 \\
\hline \multicolumn{7}{|c|}{ a. Predictors: (Constant), Pengawasan, Kedisiplinan, Fasilitas.Kerja } \\
\hline
\end{tabular}

Nilai R Square pada tabel 7. diatas adalah variabel kinerja pegawai Dinas Perikanan Kota 0,755. Hal ini menunjukan bahwa 75,50\% Tanjungbalai dapat di jelaskan oleh variabel 
fasilitas kerja, kedisiplinan dan pengawasan sedangkan sisanya sebesar $24,50 \%$ di pengaruhi oleh variabel lain yang tidak ikut di teliti.

\section{Kesimpulan}

a. Fasilitas kerja secara parsial berpengaruh positif terhadap kinerja pegawai Dinas Perikanan Kota Tanjungbalai

b. Kedisiplinan secara parsial berpengaruh positif terhadap kinerja pegawai Dinas Perikanan Kota Tanjungbalai

c. Pengawasan secara parsial berpengaruh positif terhadap kinerja pegawai Dinas Perikanan Kota Tanjungbalai

d. Fasilitas kerja, kedisiplinan dan pengawasan berpengaruh positif dan signifikan terhadap kinerja pegawai Dinas Perikanan Kota Tanjungbalai

e. Didapat nilai $\mathrm{R}$ Square sebesar 0,755. Dapat di jelaskan bahwa $75,50 \%$ variabel kinerja pegawai Dinas Perikanan Kota Tanjungbalai dapat di jelaskan oleh variabel fasilitas kerja, kedisiplinan dan pengawasan sedangkan sisanya sebesar $24,50 \%$ di pengaruhi oleh variabel lain yang tidak ikut di teliti.

\section{DAFTAR PUSTAKA}

Alwi, Safrudin. 2011. Manajemen Sumber Daya Manusia. Yogyakarta: BPFE. Ardansyah, Wasilawati. 2014. Pengaruh Disiplin Kerja dan Pengawasan

terhadap Kinerja Pegawai di Badan Pusat Statistik Kabupaten Lampung Tengah. Jurnal.

Arikunto, Suharsimi. 2010. Prosedur Penelitian. Jakarta : Rineka Cipta. Azwar, S. 2017. Metode Penilitan. Yogyakarta: Pustaka Pelajar.

Brahmasari, Ida Ayu. 2014. Pengaruh Variabel Budaya Perusahaan Terhadap Komitmen Karyawan dan Kinerja Perusahaan Kelompok Penerbitan Pers Jawa Pos. Surabaya: Disertasi Universitas Airlangga.

Cash, W.H. and F.E. Fischer. 2010. Human Resource Planning. Dalam Famularo, J.J., Hand Book of Human Resources Administration (hlm 10.310.20). Singapore: Fong and Sons Printers Pte Ltd.

Christian G. Kelatow, Adolfina, Dan Irvan Trang. 2016. Pengaruh Evaluasi
Pekerjaan, pengawasan, Dan Fasilitas Kerja Terhaadap Kinerja Pegawai pada RS. Pancaran Kasih Manado. Jurnal.

Djojowirono. 2015. Manajemen. Yogyakarta: Teknik Sipil UGM.

Erlis Mitha Sindore, Olivia Syanee Nelwan, Indrie Debbie Palandeng. 2015.

Pengaruh kedisiplinan dalam bekerja, Motivasi dan Pengawasan terhadap Kinerja Karyawan pada PT. Pertamina (Persero) Unit pemasaran VII, terminal BBM Bitung. Jurnal.

Ernie, Tisnawati Sule. 2015. Pengantar Manajemen. Depok: Prenadamedia Group.

Faisal, Mohammad Amir. 2015. Memahami Evaluasi Kinerja Karyawan, Konsep, dan Penilaian Kinerja di Perusahaan. Jakarta: Mitra Wacana Media.

Fattah, Nanang. 2014. Landasan Manajemen Pendidikan. Bandung: Remaja Rosdakarya.

Gordon, Anderson C. 2016. Managing

Performance Apprasial Systems. UK London: Blackwell Publisher.

Greenberg, J. 2015. Behaviour in Organizations: Understanding and Managing The Human Side of Work, Third Edition. Massachuscets: Allin and Bacon.

Handoko, T. Hani. 2011. Manajemen, Edisi Kedua, Cetakan Ketigabelas. Yogyakarta: BPFE.

Hartatik, Indah Puji. 2014. Buku Praktis Mengembangkan Sumber Daya Manusia. Yokyakarta: Laksana.

Hartono. 2010. Organisasi Perusahaan Teori Struktur dan Perilaku. Yogyakarta: BPFE. 2015. Paradigma Baru Manajemen

Indonesia. Jakarta: Graha ilmu.

Hasibuan, Malayu S.P. 2010. Organisasi dan Motivasi. Jakarta: Bumi Akasara.

2016. Manajemen Dasar

Pengertian dan Masalah. Jakarta: Bumi Akasara.

Husnan, Saud. 2012. Manajemen Personalia. Yogyakarta: BPFE UGM.

Kansil, C.S.T. 2012. Pokok-Pokok hukum kepegawaian Republik Indonesia. Jakarta: Pradnya Paramitha.

Kartono, Kartini, 2012. Pemimpin dan Kepemimpinan: Apakah Pemimpin 
Abnormal Itu? Jakarta: RajaGrafindo Persada.

Lupiyoadi, Rambat. 2012. Manajemen Pemasaran Jasa. Edisi 2. Jakarta: Penerbit Salemba Empat.

Mahsun, Mohamad. 2016. Pengukuran Kinerja Sektor Publik, Cetakan Pertama. Yogyakarta: BPFE.

Mangkunegara. 2011. Manajemen Sumber Daya Manusia Perusahaan. Bandung: Remaja Rosdakarya.

Mangkuprawira, Sjafri. 2012. Manajemen Sumber Daya Manusia Strategik. Bogor: Ghalia Indonesia.

Mathis, Robert L. dan Jackson, John H. 2011. Manajemen Sumber Daya Manusia Edisi 9, dialih bahasakan oleh Jimmy Sadeli dan Bayu Prawira Hie. Jakarta: Salemba Empat. 2012. Manajemen Organisasi. Jakarta: Salemba Empat.

Moenir. 2013. Manajemen Pelayanan Umum di Indonesia. Jakarta: PT. Bumi Aksara.

2015. Transformasi Pelayanan Umum di Indonesia. Jakarta: PT. Bumi Aksara.

Nitisemito, Alex, S. 2011. Manajemen Personalia. Cetakan Ketiga. Jakarta: Ghalia Indonesia.

Nurhayati, Eti. 2012. Manajemen Sumber Daya Manusia. Bandung: Yrama Widya.

Nurjaman. 2010. Pengaruh Pengawasan terhadap Kinerja Pegawai melalui Motivasi Kerja Studi kasus di Inspektorat Kabupaten Indramayu. Tesis.

Prawira, Sentono. 2011. Manajemen Produktivitas. Jakarta: Bumi Aksara. Rachman, Taufiq. 2011. Manajemen Sumber Daya Manusia Perusahaan. Bogor: Ghalia Indonesia.

Rio Marpaung dan Tri Dinda Agustin. 2013. Pengaruh Pengawasan dan Disiplin dan fasilitas kerja terhadap Kinerja Pegawai Kejaksaan Tinggi Riau. Jurnal.

Riva'i, Veithzal. 2014. Kepemimpinan dan Perilaku Organisasi. Jakarta: PT. Raja Grafindo Persada.

Robbins, Stephen P. 2015. Perilaku Organisasi. Jakarta: Salemba Empat.

$$
\text { 2016. Manajemen }
$$

Coulter diterjemahkan oleh Bob Sabran, Wibi Hardani. -Ed.10, Cet13-. Jakarta: Erlangga.

Safrudin, Alwi. 2012. Manajemen Sumber Daya Manusia. Yogyakarta: BPFE. Siagian, Sondang P. 2013. Manajemen Sumber Daya Manusia. Jakarta: CV Haji Masagung.

Simamora, Henry. 2014. Manajemen Sumber Daya Manusia. Edisi 1. Yogyakarta: STIE YKPN Yogyakarta.

Simanjuntak, Payaman J. 2015. Manajemen Evaluasi Kinerja, Edisi 3. Jakarta : Fakultas UI.

Sirait, Justine T. 2012. Memahami Aspek - Aspek Pemeliharaan Sumber Daya Manusia Dalam Organisasi. Jakarta: PT. Gramedia Widiasarana Indonesia.

Situmorang \& Juhir. 2011. Manajemen Sumber Daya Manusia. Bandung: Pustaka Setia.

Sofyan. 201. Manajemen Sumber daya

Manusia. Jakarta: PT. Elex Media Komputindo.

Sugiyono. 2010. Metode Penelitian Bisnis Cetakan kesembilan. Bandung: Alfabeta. 2013. Metode

Penelitian Pendidikan Pendekatan Kualitatif, Kuantitatif dan R \& D. Bandung: Alfabeta.

Sujak, Abi. 2013. Kepemimpinan Manajemen, Eksistensinya dalam Perilaku Organisasi. Jakarta: Rajawali Pers.

Sumarlin. 2014. Manajemen Birokrasi Indonesia. Jakarta: Ghalia Indonesia. Sumodiningrat. 2011. Pengantar Statistika. Jakarta: Andi.

Sunyoto, Danang. 2013. Manajemen dan Pengembangan Sumber Daya Manusia (Cetakan Pertama). Yogyakarta: CAPS (Center for Academic Publishing Service).

Sutiadi, 2013. Motivasi Karyawan Dan Aktifitas Manajerial Kepemimpinan Terhadap Kinerja Karyawan Pasca Sarjana Universitas Brawijaya Malang.

Tika H. Moh. Pabundu. 2016. Budaya Organisasi dan Peningkatan Kinerja Perusahaan, Cetakan Pertama. Jakarta: PT. Bhumi Aksara. Trenggono. 2018. Metode Penelitian Manajemen. Jakarta: Rajawali Pers. 
Wahyudi, Bambang. 2012. Manajemen

SUmber Daya Manusia. Bandung:

Sulita.

Ukas, Maman. 2014. Manajemen: Konsep,

Prinsip dan Aplikasi. Bandung: Agnini. 